\section{Interesting series of extra abdominal complications in two patients with chronic pancreatitis secondary to chronic alcoholism and pancreatic divisum}

Dhaval Choksi, Vikas Pandey, Prateik Poddar, Alisha Chaubal, Meghraj Ingle, Prabha Sawant

Department of Gastroenterology, Lokmanya Tilak Municipal Medical College and General Hospital, Sion, Mumbai, India

\begin{abstract}
Pancreaticopleural fistula is an extremely rare complication of chronic pancreatitis. Interestingly it may present without any symptoms of pancreatitis per se. The diagnosis requires a high index of suspicion due to the predominant thoracic symptoms. Cases with massive, rapidly refilling, refractory pleural effusion in the setting of pancreatitis (symptomatic or asymptomatic) should be suspected of having a pancreaticopleural fistula. We report two cases of pancreaticopleural fistula. One of the patient also had pancreatic divisum and to the best of our knowledge this is the first case report of pancreatic divisum with pancreaticopleural fistula in the literature.
\end{abstract}

\section{Introduction}

Pancreatitis can present with various complications, but rarely without the symptoms of pancreatitis per se. Pancreaticopleural fistula (PPF) is one such complication, seen more commonly with chronic than acute pancreatitis. It is seen in $0.4 \%$ of patients with pancreatitis. ${ }^{1} \mathrm{PPF}$ and pancreatic ascites are internal pancreatic fistulas, a term coined by Cameron et al. ${ }^{2}$ PPF presents as massive pleural effusion. The predominant thoracic symptoms cause a delay in the diagnosis. It is different from the pleural effusion of acute pancreatitis. ${ }^{3}$

We describe two patients with PPF. Neither had been previously diagnosed with chronic pancreatitis. Both had dyspnea and chest pain due to massive pleural effusion. Evaluation showed very high pleural fluid amylase levels. Endoscopic retrograde cholangiopancreatography (ERCP) diagnosed leak in one patient. Magnetic Resonance cholangiopancreatography (MRCP) diagnosed leak in the other patient.
Medical therapy failed in both. ERCP was successful in one but failed in other patient, who was managed surgically. Both the patients were asymptomatic on follow up after 1 year.

\section{Case Report \#1}

A 50 years old gentleman presented with right sided chest pain, cough and progressive dyspnea since one month. There was history of $40 \mathrm{gm} /$ day of alcohol intake for last 15 years. Patient had undergone pleural fluid tapping twice without relief.

On examination, he had fever, tachypnea, tachycardia, pallor, edema feet, ascites and right sided pleural effusion.

His hemoglobin was $6 \mathrm{gm} \%$, WBC count - 25,900/cu.mm. Albumin was $2.1 \mathrm{gm} \%$ with normal liver enzymes. Serum amylase was 1284 IU/L (0-96). Ascitic fluid amylase was $52 \mathrm{IU} / \mathrm{L}$. Pleural fluid WBC was 864 cells/cu.mm, protein (3.9 gm\%), normal adenosine deaminase level and very high amylase of 39,440 IU/L, suggestive of PPF. Chest $X$ ray showed massive right sided pleural effusion and mediastinal shift. His CT scan of the abdomen showed chronic calcific pancreatitis with dilated pancreatic duct (PD). His MRCP showed chronic pancreatitis with suspected leak in the body of pancreas. Patient underwent ERCP due to poor response to octreotide and intercostal drain and MRCP findings. Pancreatogram (Figure 1) revealed a dilated irregular PD with multiple calculi and mid body leak communicating with the right pleural cavity. Pancreatic sphincterotomy with stone extraction and PD stenting was done. Following this patient recovered completely and was discharged after 1 month.

\section{Case Report \#2}

A 28 years old gentleman, presented with left sided chest pain and progressive dyspnea since 3 months, without any abdominal complaints. There was history of consumption of 40 grams per day of alcohol for 8 years. On examination he had tachypnea and left sided pleural effusion. Chest Xray showed massive left sided pleural effusion. Pleural fluid examination showed WBC - 972/cu.mm, protein - 3.0 gms $\%$, amylase 26,491 IU/L (0-180 IU/L) and normal adenosine deaminase. Serum amylase was normal. His MRCP (Figure 2) showed moderate to severe left pleural effusion (arrow), a $3.3 \times 2.8 \times 1.4$ sized collection left of GE junction (arrow), extending into abdominal cavity through esophageal hiatus communicating with the left pleural cavity.
Correspondence: Dhaval Choksi, Department of Gastroenterology, Lokmanya Tilak Municipal Medical College And General Hospital, Sion, Mumbai, India.

Tel.: +91.9820873144 / +91.9850084244.

E-mail: dhavalrchoksi@gmail.com

Key words: chronic pancreatitis, pancreas, pancreatic divisum, pancreaticopleural fistula, pleural effusion.

Contributions: DC and AC, conception and design, analysis and interpretation of the data; PP and VP, drafting of the article; MI, critical revision of the article for important intellectual content; PS, final approval of the article.

Conflict of interest: the authors declare no potential conflict of interest.

Received for publication: 16 November 2016. Accepted for publication: 9 May 2017.

This work is licensed under a Creative Commons Attribution NonCommercial 4.0 License (CC BY-NC 4.0).

CCopyright D. Choksi et al., 2017

Licensee PAGEPress, Italy

Gastroenterology Insights 2017; 8:6974

doi:10.4081/gi.2017.6974

Another small collection in the peri-pancreatic region superior to neck of pancreas (arrow), communicating with MPD(arrow), close to the collection near GE junction was seen. Minimal irregular dilatation of PD. Type II pancreatic divisum was also seen. PD drained in the minor papilla and CBD into the major papilla. ERCP (Figure 3) with minor papilla cannulation with pancreatogram showed complete cut off at the genu. Minor papillotomy was done. Patient had no improvement with medical treatment and ERCP. He underwent distal pancreatectomy with splenectomy. Following surgery patient had good recovery and was discharged after 5 weeks.

\section{Discussion}

Pleural effusion in acute pancreatitis is seen in $3-7 \%$ of patients. ${ }^{4}$ However, pleural effusion due to PPF is seen in less than $1 \%$ of cases, suggesting its rare occurrence. ${ }^{5}$ Cameron et al suggested that if PD ruptures posteriorly, it leads to mediastinal pseudocysts and pancreaticopleural fistula. ${ }^{6}$ Pancreatic pseudocysts are seen in $43-79 \%$ of patients with PPF. ${ }^{1,7-9}$ One of our patient had peri-pancreatic collection but no pseudocyst. The most common presenting 
complaint is dyspnea $(65-76 \%) .8,9$ Pleural effusion is left sided (42-67\%), right-sided $(19-40 \%)$ or even bilateral (14-17\%). ${ }^{1,8,9,10}$ Males in mid-forties with a history of chronic alcoholism and previous episodes of pancreatitis (none of our patient had) form the classical description of PPF. Chronic Pancreatitis related to alcohol abuse $(67 \%)$ is the most common cause in adults, ${ }^{11}$ while biliary duct obstruction in children. ${ }^{12}$ Pleural fluid amylase is the diagnostic test. There is no established threshold for amylase, but it is significantly elevated $(>1000 \mathrm{U} / \mathrm{L})$, with mean levels above $10,000 \mathrm{U} / \mathrm{L} .{ }^{1,8,9,13} \mathrm{CT}, \mathrm{ERCP}$ and MRCP are used for imaging and delineating the fistula.
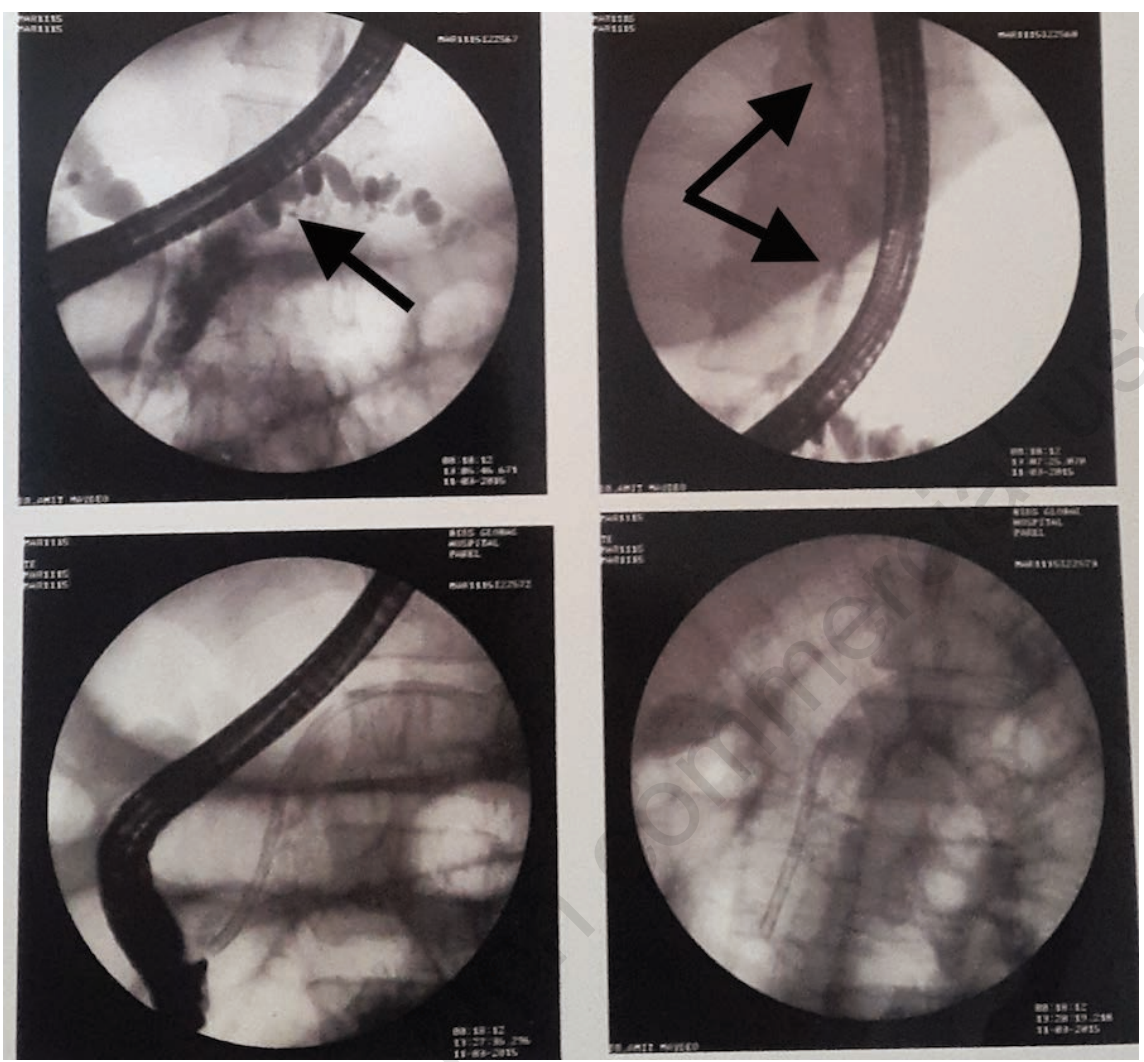

Figure 1. Pancreatogram during endoscopic retrograde cholangiopancreatography (patient 1) showing a dilated, irregular PD and mid body leak communicating with the right pleural cavity.

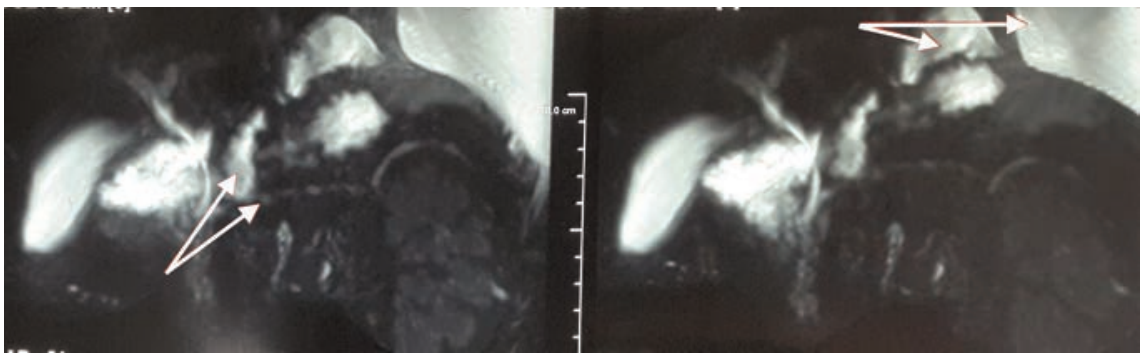

Figure 2. Magnetic resonance cholangiopancreatography (patient 2) showing left sided pleural effusion communicating with collection around GE junction (left side arrows), and peripancreatic collection with PD (right sided arrows). py. Its success rate is $31-65 \%$. $1,8,9,15$ ERCP is used as therapeutic modality because it is invasive and can cause complications like infection, pancreatitis, bleeding and perforation. ${ }^{13}$ ERCP is indicated for ductal disruptions in the head or body and a stricture downstream to the disruption. Stent placement should decompress PD. It should also preferably bridge the site of ductal disruption. The optimal duration for stent is around 4-12 weeks. ${ }^{7,13,16,17}$ It was successful in one of our patient. Surgery is used after failure of medical and endoscopic therapy. Indications are complete ductal obstruction, leak in the pancreatic tail, a downstream stricture that cannot be stented, or if the site of ductal disruption cannot be bridged by a stent. ${ }^{13}$ The operation performed commonly is distal pancreatectomy, followed by pancreaticojejunostomy. ${ }^{8}$

One patient was treated surgically. Also this patient had pancreatic divisum. To the best of our knowledge this is the first case report in the literature of divisum with PPF. However as this patient was also alcoholic, divisum alone cannot be attributed as the cause of chronic pancreatitis.

\section{Conclusions}

Pancreaticopleural fistula is a rare complication of pancreatitis. Predominant thoracic symptoms make diagnosis challenging. Awareness of the entity helps in early diagnosis and appropriate treatment. Patients not responding to conservative treatment should undergo endoscopic or surgical therapy. Pancreatic divisum in association with other known etiologies of pancreatitis may lead to not just chronic pancreatitis but also its complications like pancreaticopleural fistula.

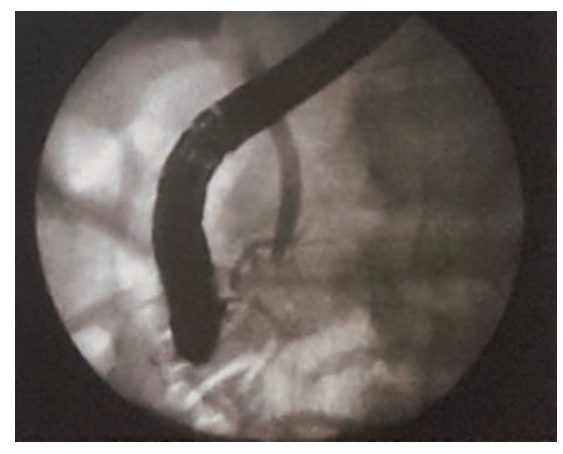

Figure 3. Endoscopic retrograde cholangiopancreatography (patient 2) showing pancreatic divisum and a pancreatogram from minor papilla revealing complete cut off at genu. 


\section{References}

1. Rockey DC, Cello JP. Pancreaticopleural fistula. Report of 7 patients and review of the literature. Medicine (Baltimore) 1990;69:332-44.

2. Cameron JL, Kieffer RS, Anderson WJ, Zuidema GD. Internal pancreatic fistulas: pancreatic ascites and pleural effusions. Ann Surg 1976;184:587-93.

3. Miller JA, Maldjian P, Seeff J. Pancreaticopleural fistula. An unusual cause of persistent unilateral pleural effusion. Clin Imaging 1998;22:105-7.

4. Materne R, Vranckx P, Pauls C, et al. Pancreaticopleural fistula: diagnosis with magnetic resonance pancreatography. Chest 2000;117:912-4.

5. Burgess NA, Moore HE, Williams JO, et al. A review of pancreaticopleural fistula in pancreatitis and its management. HPB Surg 1991;5:79-86.

6. Carthy SM, Pellegrini CA, Moss AA, et al. Pancreaticopleural fistula: endo- scopic retrograde cholangiopancreaticography and computerized tomography. AJR 1984;142:1152.

7. Safadi BY, Marks JM. Pancreatic-pleural fistula: the role of ERCP in diagnosis and treatment. Gastrointest Endosc 2000;51:213-5.

8. Ali T, Srinivasan N, Le V, Chimpiri AR, Tierney WM. Pancreaticopleural fistula. Pancreas 2009;38:e26-31.

9. Oh YS, Edmundowicz SA, Jonnalagadda SS, Azar RR. Pancreaticopleural fistula: report of two cases and review of the literature. Dig Dis Sci 2006;51:1-6.

10. Sut M, Gray R, Ramachandran M, Diamond T. Pancreaticopleural fistula: a rare complication of ERCP-induced pancreatitis. Ulster Med J 2009; 78:1856.

11. Wypych K, Serafin Z, Gałązka P, et al. Pancreaticopleural fistulas of different origin: report of two cases and a review of literature. Pol J Radiol 2011;76:56-
60.

12. Sonoda S, Taniguchi M, Sato T, et al. Bilateral pleural fluid caused by a pancreaticopleural fistula requiring surgical treatment. Intern Med 2012;51:265561.

13. Wronski M, Slodkowski M, Cebulski $\mathrm{W}$, et al. Optimizing management of pancreaticopleural fistulas. World J Gastroenterol 2011;17:4696-703.

14. Cocieru A, Saldinger PF. Frey procedure for pancreaticopleural fistula. J Gastrointest Surg 2010;14:929-30.

15. King JC, Reber HA, Shiraga S, Hines OJ. Pancreatic-pleural fistula is best managed by early operative intervention. Surgery 2010;147:154-9.

16. Machado NO. Pancreaticopleural fistula: revisited. Diagn Ther Endosc 2012; 2012:815476

17. Ridgeway MG, Stabile BE. Surgical management and treatment of pancreatic fistulas. Surg Clin North Am 1996;76:1159-73. 